ACTA AGROBOTANICA

Vol. 59, z. 12006

s. 515520

\title{
The effect of the feeding of Macrosiphum rosae (L.) and Chaetosiphon tetrarhodus (Walk.) on the flowering of roses
}

\section{BOŻENNA JAŚKIEWICZ}

\author{
Department of Entomology, University of Agriculture, ul. Leszczyńskiego 7, \\ 20069 Lublin, Poland
}

(Received: 9.05.2005)

S u m m a r y

Studies concerning the effect of the feeding of aphids Macrosiphum rosae (L.) and Chaetosiphon tetrarhodus (Walk.) on the flowering of roses were carried out in four sites in the green area of Lublin in the years 2001-2003. The studies comprised the shrubs of the park rose 'Grandhotel', the Rugosa rose, the multiflorous rose and the flower-bed roses of various cultivars. Aphids Ch. tetrarhodus dominated on Rugosa rose, while M. rosae dominated on the other roses. Aphids M. rosae and Ch. tetrarho$d u s$, when found in greater numbers, caused deformation of the leaf blades, the shortening of shoots and petioles, as well as deformation of the flowers.

Key words: Macrosiphum rosae (L.), Chaetosiphon tetrarhodus (Walk.), roses, occurrence, urban green area

\section{INTRODUCTION}

Roses are the shrubs of exceptionally decorative character, especially at during the flowering period. A lot of species are also cultivated because of the shrub habit, effective colouring of the leaves in summer in utumn and the their decorative fruit and thorns (B u g a ł a , 2000; S e n e t a and D o l a t o w s k i, 2003). Nowadays, thousands of cultivars are known whose flowers are often big, full and they smell nice, and besides, the "noble" roses usually repeat their flowering (G o t t s halk, 1991). Valuable rose oil is distilled from the rose petals and it is utilized in industry ( $\mathrm{B} \mathrm{u} \mathrm{g} \mathrm{a} \mathrm{fa}$, 2000). The massive occurrence of a number of aphid species that take their food from the fibre-vascular bundles and the parenchyma can cause considerable injuries on roses. The colonized plants have small increases, they lose their leaves earlier, flower poorly and besides, they are covered with honey-dew which lowers the decorative nature of the plants. 
The purpose of the paper was to determine the effect of the feeding of aphids Macrosiphum rosae (L.) and Chaetosiphon tetrarhodus (Walk.) on the flowering of roses in the urban environment.

\section{MATERIAL AND METHODS}

The studies concerning the effect of the feeding of aphids Macrosiphum rosae (L.) and Chaetosiphon tetrarhodus (Walk.) on the flowering of roses were conducted in the green area of the Lublin city in the years 2001-2003. The observations were made on four sites: situated close to a road (A), close to the street (B), in a housing estate (C) and in the park (D). Three shrubs of the park rose 'Grandhotel', three of Rugosa rose and three of the multiflorous rose, as well as five flower-bed roses of different cultivars were selected in each of the sites. Three shoots were randomly chosen on each shrub of flower-bed roses, while in the case of the other shrubs, five shoots were chosen. Both winged and wingless aphids (including the larvae) were counted on the shoots of similar length. The plants were observed from early spring till late autumn, with 10-days' intervals. The place of the feeding and the injuries caused by the aphids were determined.

\section{RESULTS}

The 'Grandhotel' park roses were colonized mostly by aphids Macrosiphum rosae (L.) in each of the studied years. Their total number reaching more than 47.000 individuals totally in all the years of studies, whereas the number of aphids Chaetosiphon tetrarhodus (Walk.) did not exceed 2.500 individuals. Similar results were achieved on multiflorous roses and the flower-bed roses, where $M$. rosae was the dominating species. The number of aphids $M$. rosae on multiflorous roses reached 8,552 individuals, while the population of Ch. tetrarhodus was 2.309 individuals. More than 18.000 aphids $M$. rosae were observed on the flower-bed roses, while $C h$. tetrarhodus occurred only in one year (2002) 10 individuals. On the other hand, aphids Ch. tetrarhodus were much more numerous in each year of the studies on the shrubs of Rugosa rose, their number reaching 174.020 individuals, while the population of $M$. rosae reached 11.150 individuals.

During the three years of studies, both aphid species were found in the greatest numbers on the shrubs of Rugosa rose, where more than 185.000 individuals were observed (Fig. 1). On the other hand, those aphids were the least numerous on the multiflorous roses, where almost 11.000 individuals were observed (Table 1).

The biggest number (40.931 individuals) of aphids $M$. rosae was observed on the site close to the road (A), while the smallest (12.497 individuals) was found in the park site (D). Aphids Ch. tetrarhodus were also the least numerous (5.468 individuals) in the park site (D). On the other hand, the biggest number of this species (106.681) was observed in the street site (B) (Table 2). 
The effect of the feeding of Macrosiphum rosae (L.) and Chaetosiphon tetrarhodus (Walk.) on the flowering of roses

Table 1

The number of aphids Macrosiphum rosae (L.) and Chaetosiphon tetrarhodus (Walk.) occurring on roses in 20012003.

\begin{tabular}{|c|c|c|c|c|}
\hline Rose & Year & Macrosiphum rosae (L.) & Chaetosiphon tetrarhodus (Walk.) & Total \\
\hline \multirow{4}{*}{$\begin{array}{l}\text { ark rose } \\
\text { 'Grandhotel' }\end{array}$} & 2001 & 20053 & 196 & \multirow{4}{*}{49360} \\
\hline & 2002 & 6394 & 454 & \\
\hline & 2003 & 20651 & 1612 & \\
\hline & Total & 47098 & 2262 & \\
\hline \multirow{4}{*}{ Flower-bed roses } & 2001 & 4931 & $=$ & \multirow{4}{*}{18362} \\
\hline & 2002 & 12233 & 10 & \\
\hline & 2003 & 1188 & - & \\
\hline & Total & 18352 & 10 & \\
\hline \multirow{4}{*}{ Rugosa rose } & 2001 & 7851 & 67618 & \multirow{4}{*}{185170} \\
\hline & 2002 & 2492 & 83032 & \\
\hline & 2003 & 807 & 23370 & \\
\hline & Total & 11150 & 174020 & \\
\hline Multiflorous rose & 2001 & 2923 & 31 & 10861 \\
\hline
\end{tabular}

Table 2

The number of aphids Macrosiphum rosae (L.) and Chaetosiphon tetrarhodus (Walk.) occurring on roses in particular sites in 20012003.

\begin{tabular}{|c|c|c|c|c|}
\hline \multirow{2}{*}{ Species } & \multicolumn{4}{|c|}{ Site } \\
\cline { 2 - 5 } & $\begin{array}{c}\text { Close to the road } \\
\text { (A) }\end{array}$ & $\begin{array}{c}\text { Close to the street } \\
\text { (B) }\end{array}$ & $\begin{array}{c}\text { Housing estate } \\
\text { (C) }\end{array}$ & $\begin{array}{c}\text { Park site } \\
\text { (D) }\end{array}$ \\
\cline { 2 - 5 } & \multicolumn{4}{|c|}{ Number [in specimens] } \\
\hline $\begin{array}{c}\text { Macrosiphum rosae } \\
\text { (L.) }\end{array}$ & 40931 & 14455 & 17269 & 12497 \\
\hline $\begin{array}{c}\text { Chaetosiphon } \\
\text { tetrarhodus (Walk.) }\end{array}$ & 39758 & 106681 & 26694 & 5468 \\
\hline Total & 80689 & 121136 & 43963 & 17965 \\
\hline
\end{tabular}

Aphids $M$. rosae at first fed on the developing leaf buds, and next they moved to the leaves, the top parts of the shoots, the flower buds and the sepals. Individual specimens were also found on the rose petals. This species occurred in two colour varieties, namely green and pink ones (Fig. 2). The green individuals were observed throughout the period of vegetation, while the pink ones were found in spring and autumn. In the summer time of the studied period partial or complete disappearance of the aphids of this species was observed on the analyzed shrubs.

The pale green individuals of Ch. tetrarhodus on Rugosa rose occurred in exceptionally big numbers, covering the bottom part of the leaf blades, the top parts of the shoots, the pendicles and the flower buds. In summer they fed most frequently on older leaves and on the shoots between the strigose thorns. This species was observed irregularly on the shrubs of the park rose 'Grandhotel', the multiflorous rose and the flowerbed roses, and its number was several times as low. In the years when the number of both species of aphids was very big, we observed deformation of the leaf blades, the shortening of the shoots and petioles, deformation of the flowers, as well as the secreted honeydew. Those injuries significantly lowered the decorative value of the studied plants. 


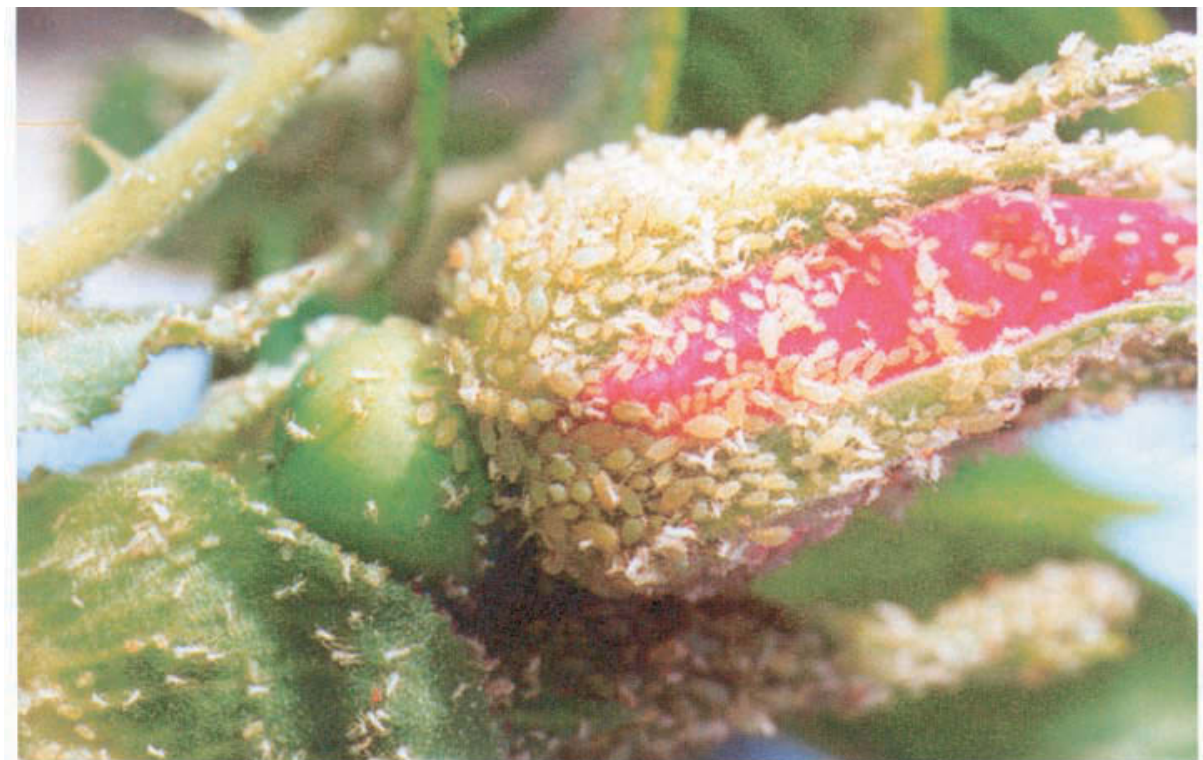

Fig. 1. Macrosiphum rosae (L.) and Chaetosiphon tetrarhodus (Walk.) on the floral bud of the Rugosa rose.

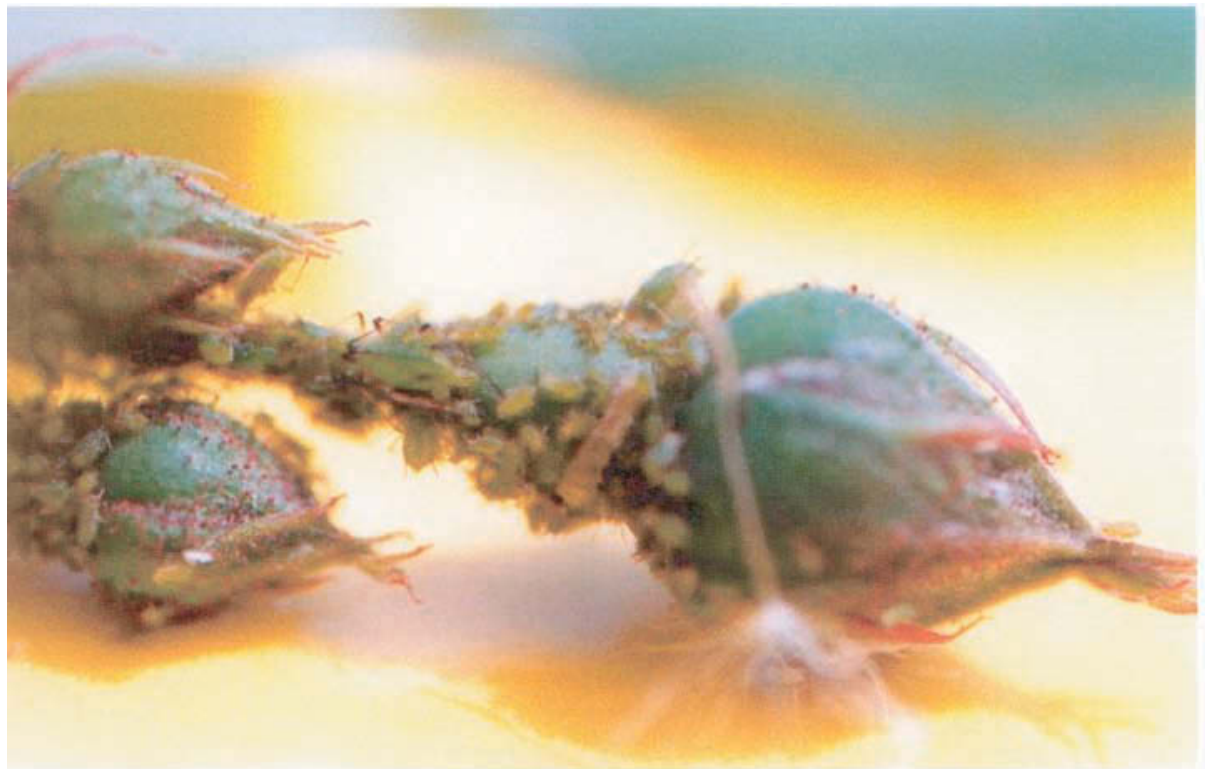

Fig. 2. Macrosiphum rosae (L.) on the floral bud of rose. 


\section{DISCUSSION}

M. rosae is the species whose presence was observed in each year studied on the roses from each utility group and on each of the examined sites, which testifies to its widespread occurrence. In a number of items of literature, this aphid is described as the species occurring on roses most frequently and in the greatest number (C i c h o c k a and J a śki e wi c z, 2003; J ási e wi c z, 1997b, 1999, 2000, 2003).

Ch. tetrarhodus is the species observed on roses from each utility group; however, it did not occur every year and not in all sites. Individual specimens were found on the flower-bed roses only in the year 2002. It occurred in small numbers on the shrubs of the 'Grandhotel' park rose, especially in the year 2001. C i c h o c k a and J a ś ki e w i c z (2003) write about bigger number of this species on wild roses as compared to the noble ones, at the same time mentioning its increasing importance in the last 30 years. On the other hand, in earlier literature this aphid was described as the species occurring on roses in small numbers, also on Rosa rugosa ( $\mathrm{J}$ a ś k i e w i c z , 1995, 1997a).

Bigger number of aphids were found on roses in the site with increased traffic as compared to the park site. The above data confirm the results of studies that point out that in the polluted urban environment observed increasing numbers of insects with the stinging-sucking mouth apparatus were observed (C i c h o c k a and G o s z c z y ń s k i, 1991; J a śk i e w i c z, 2003).

The feeding of aphids causes deformation of shoots and leaves on host plants, checking their growth and leading to poorer blooming and fructification. Besides, the honey-dew secreted by aphids sticks up the stomata, in this way making the gas exchange difficult and disturbing the processes of assimilation (C i ch o c ka, 1980; Cichocka and Goszczyński, 1986). Aphids Ch. tetrarhodus and particularly $M$. rosae, when found in greater numbers, checked the growth of the shoots, caused deformation and discoloration of the leaves and deformation of the flower buds and flowers. Besides, the plants were covered with honey-dew, where saprophytic fungi marring the plants developed. Similar information is given by Cichock a (1980) and J a śk i e w i c z (1997a, 1999, 2003).

\section{CONCLUSIONS}

1. Aphids Chaetosiphon tetrarhodus (Walk.) dominated on Rugosa rose, while Macrosiphum rosae (L.) dominated on the other roses.

2. Both aphid species were most numerous on the shrubs of Rugosa rose, and the least numerous on the multiflorous rose.

3. The biggest number of aphids Macrosiphum rosae (L.) was observed on the roses in the road site (A), while Chaetosiphon tetrarhodus (Walk.) dominated in the street site (B). Aphids of this species were the least numerous on the roses in the park site (D).

4. Aphids Macrosiphum rosae (L.) and Chaetosiphon.tetrarhodus (Walk.) fed on the leaves, the top parts of shoots, petioles and flower buds, as well as on the sepals. Clear injuries of the plants, such as deformation of the leaf blades, the shortening of the shoots and petioles, deformation of the buds and flowers, were observed with bigger populations of the aphids, particularly M. rosae. 


\section{REFERENCES}

B u g a ł a W., 2000: Drzewa i krzewy. PWRiL, Warszawa, pp. 614.

C i ch o c k a E., 1980: Mszyce roślin sadowniczych Polski. PWN, Warszawa, pp. 119.

C i ch o c k a E., G o s z c z y ń s k i W., 1986: Biologia odżywiania i bezpośrednia szkodliwość mszyc. Zesz. Probl. Post. Nauk Rol. 329, 723.

C i c h o c k a E., G o s z c z y ń s k i W., 1991: Mszyce zasiedlające drzewa przyuliczne w Warsza wie. W: Mszyce ich bionomia, szkodliwość i wrogowie naturalni (red Cichocka E., Goszczyński W.), PAN, Warszawa, 918.

Cichocka E., Jaśkiewicz B., 2003: Aphids inhabiting roses in diferent culture in 1967 2003. Aphids and Other Hemipterous Insects, Monograph, PAG, Rogów, 9, 1736.

G o t t s c h a lk W., 1991: Poradnik dla miłośników róż. PWRiL, Warszawa, pp. 169.

J a ś k i e w i c z B., 1995: Zespół gatunków mszyc żerujących na krzewach Rosa rugosa Thunb. W Parku Akademickim w Lublinie. Ann. Univ. Mariae Curie Skłodowska EEE Hort. III, $18,145158$.

J a ś k i e w i c z B. 1997a: Skład gatunkowy i dynamika pojawu mszyc na wybranych krzewach ozdobnych w latach 1973 1993. Rozprawa habilitacyjna. Wyd. Akad. Roln. Lublin. Rozpr. Nauk. 183, 93 pp.

J aśkiewicz B., 1997b: Observations on the occurrence of the rose aphid (Macrosiphum rosae L.) on bushes of Rosa rugosa Thunb. and R. canina L. Folia Hortic. 9, 2531.

J aśki ewicz B., 1999: Aphids on chosen ornamental shrubs in Lublin. Aphids and Other Homopterous Insects, PAS Olsztyn, 7, 6773.

J aśki e w i c z B., 2000: Aphids colonising the shrubs of Juniperus communis L. and Rosa canina L. in urban conditions. Electronic Journal of Polish Agricultural Universities, Series Horticulture, Issue 3, www.ejpau.media.pl.

J aśk i e w i c z B., 2003: Dynamika populacji mszyc Macrosiphum rosae (L.) zasiedlających krzewy Rosa sp. Na terenach zieleni miejskiej Lublina. Ann. Univ. Mariae Curie Skło dowska, Sect. EEE Hort. XIII, 271278.

Senet a W., D ol at ow ski J., 2003: Dendrologia. PWN, Warszawa, pp. 559.

\section{Wpływ żerowania Macrosiphum rosae (L.) i Chaetosiphon tetrarhodus (Walk.) na kwitnienie róż}

\section{Streszczenie}

Badania dotyczące wpływu żerowania mszyc Macrosiphum rosae (L.) i Chaetosiphon tetrarhodus (Walk.) na kwitnienie róż prowadzono w latach 2001-2003 na terenie zieleni miejskiej Lublina na czterech stanowiskach. Badaniami objęto krzewy róży parkowej 'Grandhotel', róży pomarszczonej, róży wielokwiatowej oraz róże rabatowe różnych odmian. Na róży pomarszczonej dominowała mszyca Ch. tetrarhodus, natomiast na pozostałych różach $M$. rosae. Mszyce $M$. rosae oraz Ch. tetrarhodus przy liczniejszej obecności powodowały zniekształcenie blaszek liściowych, skracanie pędów i szypułek kwiatowych oraz deformacje kwiatów. 